\title{
Consumer Behavior of College Students in the Czech Republic
}

\section{- Horáková Monika}

\begin{abstract}
This contribution is a follow-up to the topic of consumer behavior which is analyzed from the economic theory perspective on microeconomic as well as a macroeconomic level. The main objective of the article is to reveal the structure of college students' consumer basket determined according to disposable income and its changes. In this article, the methodology of a consumer basket was used. The division of it was done by Czech Statistical Office to calculate the inflation rate in the environment of the Czech Republic. In this article, the analysis of college students' consumer basket was done. The pressure on having a higher qualification in tertiary education is a typical trend across Europe, which is also one of strategic goals of EU Strategy 2020 and its concept. There is clear evidence of a growing segment of college students that represents a significant demand group on the product and service market. The knowledge of their consumer habits is definitely beneficial for companies regarding their competitive advantage and reaching higher incomes from the products offered. The market product consumption is dependent on the total disposable income mainly. That is fundamentally dependent on hours of paid work or other fund contributions. The current disposable income shows the differences regarding consumption expenditures of a consumer basket and its various categories. A lower disposable income is typical for flowing the highest consumer expenditures from class 1 (Food and non-alcoholic beverages) to class 4 (Housing, water, electricity, gas and other fuels) of a higher disposal income. If the current disposable income of college students increases, there would be higher consumption expenditures regarding classes 9, 3 and 5 (Recreation and culture; Clothing and footwear; Furnishings, household equipment and routine household maintenance). On the contrary, a lower disposable income would mean lower expenditures regarding classes 3, 2 and 9 (Clothing and footwear; Alcoholic beverages and tobacco; Recreation and culture).
\end{abstract}

Keywords: college student, disposable income, consumer basket, consumer expenditures JEL Classification: D12, E21

\section{INTRODUCTION}

Final consumption expenditures of households are one of macroeconomic components of national as well as international methodologies to measure the economy product. There is an expenditure approach use in the Czech Republic. (Czech Statistical Office, 2015a) According to the statistics, these expenditures form about half of the final GDP sum. Therefore, it is not possible to ignore this national component. (Eurostat, 2015c) Although there are about 10.5 million people (households) in Czech economy, only one part (about 59\% of them) are within the category of being economically active. The rest of population is represented by seniors mainly, children and handicapped people. (Czech Statistical Office, 2015c) The economic activity on the labor 
market is connected with incomes, which can be even higher by adding other finances from state or other persons. We can call this a disposable income. Subsequently, these incomes are used to buy products and services, and this can be called consumer expenditures. It is essential to monitor distribution of these financial incomes by the state as well as companies in practice. The consumer expenditures support better economy performance (growth of GDP), and the companies have better possibilities regarding potential market for their production. A growing consumer interest in companies' products means having higher sales, profit, and the companies are becoming more competitive.

Strategy Europe 2020 accepted by EU countries has set the goal in 5 key areas to reach an economic growth and a higher employment rate. This concept supports the present focus of the article on the field of education where the percentage of people with a university degree (age 30 - 40) should reach 40\% respectively 32\% in Czech Republic. (Eurostat, 2015b) Therefore, the group of college students represents a significant market potential nowadays and for the future as well. Results of the research show behavior of current group of college students within consumer behavior depending on disposable income.

College students' behavior is part of microeconomic as well as macroeconomic scientific discipline. In the following subchapters, the bipartite view on these issues will be presented.

\subsection{Consumer Behavior - Macroeconomics Point of View}

A consumer is every economic individual on the demand side. A consumer enters the product and service market in order to satisfy individual needs. (Krugman \& Wells, 2009; Rubinfeld \& Pindyck, 2013) Regarding a consumer, there are many factors influencing the consumer's attitude and his/her preferences thank to which consumer's decision about buying is made. (Besanko et al, 2015; Clemons, 2008)

All the individuals entering the market with the aim to satisfy their needs through buying products or services are becoming consumers at the same time. The financial income enables such buying and consumption itself. From the national economy perspective, financial incomes as well as consumption expenditures of households are monitored. Such methodology connected with the finding above mentioned is called - Statistics on Income and Living Conditions (EUSILC). The range of SILC results usage is rather wide. It is a base for state social politics, for internal statistics of Czech Statistical Office (CSO), e.g. forming a consumer basket to check a consumer prices index CPI, which is a supporting source to form national accounts within household sector as a part of the economy product, and for comparison on international level as well. (CSO, 2015d)

The particular financial amount spent on getting a product is called consumption expenditure. Czech Statistical Office (CSO) in accordance with EU directives divides individual consumption expenditures into 12 basic categories (see Tab. 1). These categories also include products and services of common daily consumption. This division collects information regarding consumption expenditure according to the Classification of Individual Consumption by Purpose (COICOP). Such streamlined list is called a consumer basket. To each principal category, more precisely to all products and services included, there is information added regarding their level of consumption value, in total weight of $1,000 \%$. 
Tab. 1 - Structure of Consumer Basket by COICOP (Source: CSO, 2015d)

\begin{tabular}{|l|l|c|}
\hline \multicolumn{2}{|l|}{ COICOP (CP01-12) } & $2012^{*}$ \\
\hline CP01 & Food and non-alcoholic beverages & 170,332703 \\
\hline CP02 & Alcoholic beverages, tobacco and narcotics & 85,987255 \\
\hline CP03 & Clothing and footwear & 47,207768 \\
\hline CP04 & Housing, water, electricity, gas and other fuels & 253,400912 \\
\hline CP05 & $\begin{array}{l}\text { Furnishings, household equipment and routine } \\
\text { household maintenance }\end{array}$ & 55,190047 \\
\hline CP06 & Health & 24,998575 \\
\hline CP07 & Transport & 114,887081 \\
\hline CP08 & Communications & 39,882587 \\
\hline CP09 & Recreation and culture & 93,682015 \\
\hline CP10 & Education & 7,768676 \\
\hline CP11 & Restaurants and hotels & 44,258026 \\
\hline CP12 & Miscellaneous goods and services & 62,404355 \\
\hline
\end{tabular}

*Source: The average weights of 2015 have been on the same level since 2012.

Monitoring the aggregated consumption expenditures is part of a GDP calculation done by an expenditure approach. (Mankiw, 2014)

In this article, we will also be interested in understanding consumer basket structure from consumption expenditures perspective with regard to particular principal categories. In the national context, these final expenditures form part of family accounts statistics.

\subsection{Consumer Behavior - Microeconomics Point of View}

On the contrary, it is not possible to state that all the consumers on the market behave in the same way as each individual is specific. To reveal consumer behavior in the period of modern technologies, e.g. internet, means a special task for every company in business. It is to find the way to Pandora's box. (Gurney, Chambers, Grant, Shah and Sullivan, 2004)

The consumer decision-making itself regarding buying a product is influenced by many external factors, such as economic conditions, social level, legislation, as well as by internal factors, e.g. psychological factors, opinions, attitudes.

From the market offer perspective, it is essential for the companies to include all the aspects within marketing selling strategies in order to motivate a customer to buy the product.

An economically simplified marketing model of consumer behavior is visible in Figure 1 (Schifmann \& Kanuk, 2007; retaken by Stávková \& Stejskal, 2011) 


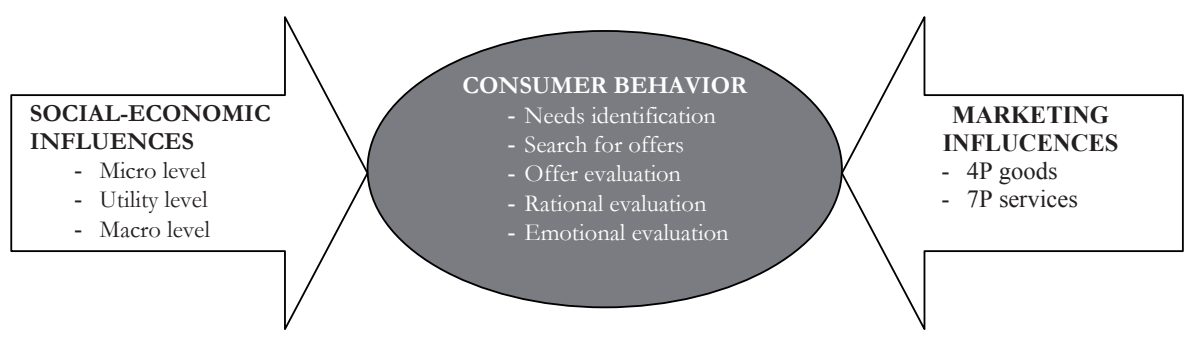

Fig. 1 - Model of consumer behavior and decision making (own processing; Source: Schifmann \& Kanuk, 2007; retaken by Stávková \& Stejskal, 2011)

The principal aspect for retailers to understand a consumer trend is understanding of their final segment. Each consumer is characterized by his or her shopping behavior that undoubtedly affects the educational qualification and disposable income. Understanding of such trends and suitable application in marketing selling strategy enable companies to have higher sales and thus contribute to having a higher profit.

\section{THEORETICAL BACKGROUND}

\subsection{Students and Tertiary Education in the Czech Republic}

The aggregated point of view regarding university studies official statistics enables to see the development tendency within Czech university environment.

From the following absolute frequencies in Tab. 2 regarding number of students in tertiary education, it is possible to see a growing trend in the interest of Czech population in university education for the academic year 2011/2012. The following two years were typical for a slight decline. Still, the numbers are over 370 thousand students in the CR.

There are two basic forms of study in the Czech Republic - full time study and part time study. The second one is in majority preferred by people already working.

Tab. 2 - Number of College Students in the Czech Republic 2005 - 2013 (Source: CSO, 2014a)

\begin{tabular}{|l|c|c|c|}
\hline Academic year & $\begin{array}{c}\text { Number of full time } \\
\text { students }\end{array}$ & $\begin{array}{c}\text { Number of part-time } \\
\text { students }\end{array}$ & TOTAL \\
\hline $2005 / 06$ & 223154 & 68689 & 291843 \\
\hline $2006 / 07$ & 238172 & 80778 & 318950 \\
\hline $2007 / 08$ & 251903 & 95347 & 347250 \\
\hline $2008 / 09$ & 263897 & 107987 & 371884 \\
\hline $2009 / 10$ & 277051 & 116293 & 393344 \\
\hline $2010 / 11$ & 283528 & 116736 & 400264 \\
\hline $2011 / 12$ & 284256 & 111956 & 396212 \\
\hline $2012 / 13$ & 281897 & 102726 & 384623 \\
\hline $2013 / 14$ & 277621 & 94014 & 371635 \\
\hline
\end{tabular}


Tertiary education in the Czech Republic is regulated by the Higher Education Act No. 111/1998 Coll. (CMŠMT, 2013-2015) At present, all public universities (26 in total), state universities (2 in total) and private universities (43 in total) must follow these regulations.

The truth is that young people often use university as a tool to postpone their working duties on the labor market. According to CSO's research, Czech students definitely enter the labor market much later than other students do in other countries of Europe. "The Czech Republic is typical for its long tertiary education period." The roots of such trend can be recognized in the first classes of primary school when many children start their compulsory education later at the age of 7 or 8 . (CSO, 2012b)

At foreign universities, it is common to enter the labor market after reaching bachelor degree whereas in the CR, $60 \%$ of students continue in their studies on master level. Government representatives should strive to change this trend through the system of specialization and diversification of universities according to quality indicators. (Fiala, 2012)

External economic circumstances (unemployment, economic growth, development of a national debt) also have a strong influence on tertiary education market. There will be a lower number of buyers (students) in the following years (less children born) and this will be reflected in the offer (universities). A lower number of students at some universities will cause a higher degree of competitiveness among these (as well as faculties themselves). They will strive to influence the university applicants. Also, their aim will be to keep the students at particular university. The most important aspect regarding decision-making is the choice of a study program and its characteristics (pedagogical staff, financial demands of studies, educational and accommodation facilities). (Enache, 2011)

In the Tab. 3 below, the structure of financial household expenditures is recorded in accordance with COICOP and households of various level of qualification. In the first column, a total household average within economy is stated. In the following two columns, consumer expenditures of lower and higher education are compared. The level of education is stated in accordance with CSO in the following way:

- Lower education $=$ persons with primary education, qualified or completed secondary education without taking A-levels.

- Higher education $=$ persons with completed secondary education with passing A-levels, with higher degree of education or university degree.

Tab. 3 - Average consumer expenditures by purpose (COICOP) per capita 2014 according to the education level (own processing; Source: CSO, 2015d)

\begin{tabular}{|l|l|c|c|c|}
\hline \multicolumn{2}{|l|}{$\begin{array}{l}\text { CONSUMER EXPENDITURES, } \\
(\text { CZ-COICOP })\end{array}$} & $\begin{array}{c}\text { Household } \\
\text { total* }\end{array}$ & $\begin{array}{c}\text { Employee } \\
\text { with lower } \\
\text { education* }\end{array}$ & $\begin{array}{c}\text { Employee } \\
\text { with higher } \\
\text { education } *\end{array}$ \\
\hline 01 & Food and non-alcoholic beverages & 20,3 & 21,1 & 17,6 \\
\hline 02 & $\begin{array}{l}\text { Alcoholic beverages, tobacco and } \\
\text { narcotics }\end{array}$ & 2,9 & 3,4 & 2,3 \\
\hline
\end{tabular}




\begin{tabular}{|c|l|c|c|c|}
\hline 03 & Clothing and footwear & 4,9 & 4,9 & 5,7 \\
\hline 04 & $\begin{array}{l}\text { Housing, water, electricity, gas and } \\
\text { other fuels }\end{array}$ & 21,5 & 20,6 & 18,6 \\
\hline 05 & $\begin{array}{l}\text { Furnishings, household equipment } \\
\text { and routine household maintenance }\end{array}$ & 5,7 & 5,7 & 6,0 \\
\hline 06 & Health & 2,6 & 2,1 & 2,3 \\
\hline 07 & Transport & 10,5 & 11,4 & 12,2 \\
\hline 08 & Communications & 4,2 & 4,5 & 4,1 \\
\hline 09 & Recreation and culture & 9,5 & 8,3 & 10,7 \\
\hline 10 & Education & 0,6 & 0,6 & 0,8 \\
\hline 11 & Restaurants and hotels & 5,3 & 5,1 & 6,8 \\
\hline 12 & Miscellaneous goods and services & 12,0 & 12,4 & 13,0 \\
\hline
\end{tabular}

It is possible to state the following facts when comparing consumer expenditures of people with lower vs. higher education:

- People with higher education spend less on items from category $1=$ Food and non-alcoholic beverages, category $2=$ Alcoholic beverages and tobacco, category $4=$ Housing, water, electricity, gas and other fuels.

- People with higher education spend more on items from category $3=$ Clothing and footwear, $7=$ Transport, $9=$ Recreation and culture, $10=$ Education, $11=$ Restaurants and hotels, and $12=$ Miscellaneous goods and services.

- People with higher education exceed people with lower education in a total average across the republic in the items from categories 3, 5, 7, 9, 10, 11 and 12 .

From the aggregated data, it is possible to distinguish what products and services the people with higher qualification seek. Following this fact, companies of various specializations can concentrate on particular types of consumers according to their needs. Therefore, they can use their marketing strategies and contribute to higher sales and profit.

Another indisputable source of information, which stresses the importance of a market segment formed by university students, is provided by a strategy of European Union called Europe 2020. This strategy was set for all EU members with the aim to support the economic growth and employment. The strategy sets 5 key areas measured by 9 indicators. Every country strives to get close to these target values, and has set national goals with regard to its economic, political and social situation. (Eurostat, 2015b)

The Czech Republic accepted this strategy on 17 July 2010. Two work-connected key areas and three measured indicators are mentioned here. The government of the Czech Republic must strive to fulfil these before the year 2020. In the Tab. 4, there is a present development of indicators from the year 2010 to the year 2014. These areas are linked to consumer behavior of Czech students when the importance is stressed on the area of education and employment. 
Tab. 4 - Strategy Europe 2020 and main targets, development of indicators for the Czech Republic (own processing, Source: Eurostat, 2015b)

\begin{tabular}{|c|c|c|c|c|c|c|c|c|}
\hline Key area & Indicator & $\begin{array}{c}\text { target } \\
\text { EU }\end{array}$ & $\begin{array}{c}\text { target } \\
\mathrm{CZ}\end{array}$ & 2010 & 2011 & 2012 & 2013 & 2014 \\
\hline $\begin{array}{l}\text { Employ- } \\
\text { ment }\end{array}$ & $\begin{array}{l}\text { Unemployment rate } \\
20 \text { - } 64 \text { years }(\%)\end{array}$ & 75,0 & 75,0 & 70,4 & 70,9 & 71,5 & 72,5 & 73,5 \\
\hline \multirow[b]{2}{*}{ Education } & $\begin{array}{l}\text { Early leavers from } \\
\text { education system }(\%)\end{array}$ & $<10$ & 5,5 & 4,9 & 4,9 & 5,5 & 5,4 & 5,5 \\
\hline & $\begin{array}{l}\text { Tertiary education } \\
\text { people age } 30-34 \\
(\%)\end{array}$ & $\geq 40$ & 32,0 & 20,4 & 23,7 & 25,6 & 26,7 & 28,2 \\
\hline
\end{tabular}

The key target within education in the CR is to reach $32 \%$ of people with a university degree. According to present development trend, it is expected to meet this target before the year 2020 . The question is how the Higher Education Amendment Act from 1 September 2015 will influence this indicator. The aim of the amendment is a stabilization process of tertiary education through a new method of quality evaluation of universities (introduction of new rules within study programs accreditation, independent professional decision-making regarding accreditations, establishment of Accreditation Office and making new rules for foreign universities in the CR). (CMŠMT, 2013-2015)

\subsection{College Student and Consumer Behavior}

There is a vivid discussion among some authors regarding their view on a student as the subject of consumer behavior. The question is whether it is a relevant individual who can predict a consumer behavior development or vice versa, which means to deny many findings of marketing studies. It is definitely a specific market segment that is typical for its buying habits. These can be reflected in the upcoming years when not having the role of a student any more. According to Enis et al. (1972), every research within the segment of students should ask the question if the data obtained would be credible enough for the purpose of research and development.

There is a wide range of foreign studies dealing with university students' behavior in connection with product and services consumption opening many debates within society about its mainly negative impact on human being. Such products are cigarettes and tobacco products, alcohol consumption, or narcotics. (O’Connor \& Lundstrom, 2011; Zilberman \& Poole, 2009)

According to Zilberman and Poole (2009), there is higher alcohol consumption during university studies, mainly when having parties. This consumption is then analyzed from the finances perspective. Two thirds of US students consider the alcohol consumption as reasonable, when costs of this consumption category form $1 / 4$ of their total expenditures. Only $1 / 3$ of students consider their own expenditures on alcohol as excessive, even though almost $75 \%$ of them declare that their colleagues spend more money on alcohol than they should. Family background and parents' education are most discussed areas from psychosocial aspects influencing the studies. Then, it is sexual adaptation, multicultural adaptability, religion or suicidal tendencies. (Luquis et al., 2012) 
When buying, the university students are also influenced by marketing tools. These are sales, buy one get one free or loyalty bonuses which are most efficient selling techniques. (Osman \& Fah, 2011) Not only companies but also students themselves are aware of advanced technological progress. Plenty of students cannot imagine living without modern "gadgets" such as smartphone, iPad, laptop, MP3/MP4 player, printing machine or game console. (La Roche, Flanigan \& Copeland, 2010)

The marketing research aimed at consumer behavior of US university students describes the structure of their consumer expenditures. In the year 2012, there was a consumer demand of students $40 \%$ higher thanks to higher intentional expenditures (expenditures above the compulsory expenditures needed supporting consumerism). On the contrary, not intentional expenditures (tuition fees, accommodation, study materials) experienced a slight decline in total expenditures. Across the consumer basket, US university students spent twice more on particular items within expenditures in the academic year 2012/2013:

- clothing (126\% higher),

- technology (227\% higher),

- personal care products (105\% higher),

- cosmetics $(280 \%$ higher).

Another area of research was focusing on students' particular way of dieting. The highest amount of money the students spend in retail stores (supermarkets and hypermarkets) - about 47 $\%$. Then, it is in restaurants and student refectories (31\%) and in small shops, e.g. convenience stores (22\%). (Miller and Washington, 2013)

Tuition fees also form an important part of students' expenditures in western countries. The CR has not introduced tuition fees at tertiary education (except the fees in a private education sector), which is the consequence of lower regular common expenditures than in the countries where tuition fees are typical. This was a topic widely discussed at the end of the year 2012. At that time, speculations regarding the introduction of tuition fees occurred across the political spectrum. (Fiala, 2012) At present, in 2015, the politicians dedicate their time to questions regarding tertiary education quality and its improvement mainly. Another important topic of these days is employment of graduates on the labor market.

As mentioned at the beginning, a student as a consumer has various possibilities of financing his/her consumption. Student loans from governments through banks to cover tuition fees are typical for western countries. As shown in US study focused on student loans, students do not use the loans just to pay tuition fees but also to cover their regular consumer expenditures in the last five years, e.g. accommodation, transport or health care. (Ebersole, 2012)

In the environment of Czech banking companies, there is a high degree of competitiveness with the aim to have customers within the group of university students. It is expected that these customers will stay the customers of the banking company even after finishing their studies, which means higher incomes for the banks. Fees for administration of bank accounts and services mainly influence Czech students. (Kuběnka \& Ptáčková, 2011) 
As Baňařová states (2014), students consider large banks with a rich history as the most popular ones, e.g. Česká spořitelna, Komerční banka or Československá obchodní banka. All these banks offer student packages and people recognize them as stable ones. Another reason for choosing services of these banks can be low fees of student accounts they offer as well as service satisfaction, namely internet banking and having a chance of using debit cards.

According to Xiao et al. (2011), the main source of financing consumption in the last few years has been usage of credit cards and accessible overdraft accounts to cover expenditures. Having not only one credit card makes students owing. Not all the students are aware of risks connected with using the credit. Students believe that they know than what they are aware of, and such attitude influence their behavior in a significant way.

The most significant items of a consumer basket belong to category 4 Housing, water, electricity, gas and other fuels. As seen from the research focused on US university students, more than half of the students (about $53 \%$ ) live with their parents, $25 \%$ renting a place, $18 \%$ using university halls of residence, and $4 \%$ living in the groups of sisterhood or brotherhood. (Miller \& Washington, 2013) Following this fact, more than half of the students live in a so-called impute rent.

According to Wanninyake (2014), a consumer behavior research among Czech university students proved the existence of link regarding home product brands and services. The respondents of this study were characterized as impulsive in the area of fashion and recreation. However, the price was an important factor for them. A Czech customer with a lower income (a student) behaves as spontaneously when buying as people with a higher income do. Therefore, this is the market potential for companies offering Czech products and brands, e.g. farm shops.

Although students throughout their study process are not aware of it, there is a positive externality influencing them and helping them to get rid of stress that was caused when doing other activities. Among these pleasant activities, which can every university itself offer through its study programs, for example sports are. (Wan-Chi et al., 2012) It is very important to consider strong elements to accept a student at university and to motivate a student in order to finish the studies successfully. These are the teachers themselves (having a positive and open approach, having feedback from students, knowledge), teaching methods (preference of stimulating methods, brainstorming, role-plays, team projects) and the atmosphere within a group (pleasant atmosphere, cooperation). (Halawah, 2011) In case the problems occur in some of the areas evaluated, there is a consulting authority to reveal them. Such authority is a common standard in western countries. (Wells \& Lynch, 2012)

\section{METHODOLOGY}

The composition of the selection of respondents for the survey included full-time students and part-time students of the master's degree program. The students were fundamentally sorted according to the level of disposable income. All respondents were addressing students of the Faculty of Management and Economics of Tomas Bata University in Zlin (FaME TBU). This primary research was conducted in 2014. The sample of students participating in the survey was in total of 436. The questionnaires were filled out electronically via the web store Google Disk. 
Information obtained from the questionnaires were analyzed by using MS Excel 2013. Then, these data were drawn up into contingency table (Table 5) for the independence testing. This independence has been calculated by using statistical methods of Pearson's Chi-square test of independence $\left(\chi^{2}\right)$.

The first goal was to show a dependence (independence) time devoted to paid work according to the level of disposable income. Funds raised from the paid work determine the factor of time spent on paid work per day.

Nevertheless, the data from consumer basket were evaluated and the highest values were averaged. The answers reflected the current situation of the college students segment. Subsequently, the structure of students' consumer basket for the year 2014 was illustrated in the Table 6. Finally, changes occurred in the consumer basket which were caused by increasing or decreasing disposable income, and determined by individual needs of students.

\subsection{Hypothesis Testing}

The purpose of the questionnaire is to verify whether the amount of hours of paid work depends on the category of the level of disposable income. All students were segmented into five groups according to the amount of disposable income to four income intervals:

- up to 5,000 CZK (no. 105; 24\%);

- 5,001 - 11,000 CZK (no. 149; 34\%);

- 11,001 - 17,000 CZK (no. 89; 21\%);

- above 17,000 CZK (no. 93; 22\%).

As Cooper and Schindler (2008) describe the process of hypothesis testing, there has been one hypothesis stated which are based on theoretical background regarding the level of disposable income of college students and number of hours devoted for paid work. For statistical verification of the amount of hours devoted to paid work, which allows consumption was determined null hypothesis $\left(\mathrm{H}_{0}\right)$ and alternative hypothesis $\left(\mathrm{H}_{\mathrm{A}}\right)$.

$\mathrm{H}_{0}$ : The number of hours devoted to paid work does not depend on disposable income.

$\mathrm{H}_{\mathrm{A}}$ : The number of hours devoted to paid work does depend on disposable income.

Subsequently, the data were tested by Pearson's Chi-square independence test $\left(\chi^{2}\right)$ done in MS Excel 2013 for Windows. This program enables to calculate p-value on the stated importance level for accepting or rejecting null hypothesis. In this study, the result of $\mathrm{p}$-value was compared with significance level $\alpha=5 \%$. If the result is lower than significance level the null hypothesis is rejected and alternative hypothesis is accepted.

\section{RESULTS}

\subsection{Hypothesis Testing}

For testing the hypothesis of independence through Pearson's square test was compiled following contingency Table 5. 
Tab. 5 - Contingency table of time allocation to paid work according to level of disposable income (own processing)

\begin{tabular}{|l|l|c|c|c|c|c|}
\hline \multirow{2}{*}{$\begin{array}{l}\text { Disposable income } \\
\text { interval }\end{array}$} & \multirow{2}{*}{ Number } & \multicolumn{5}{|c|}{ Time to paid work (in hours) } \\
\cline { 3 - 7 } & & $0 \mathrm{~h}$ & $1-2 \mathrm{~h}$ & $3-4 \mathrm{~h}$ & $5 \mathrm{~h}$ above & Total \\
\hline \multirow{2}{*}{ up to 5,000 CZK } & absolute & 59 & 29 & 10 & 7 & 105 \\
\cline { 2 - 7 } & relative $\%$ & $56 \%$ & $28 \%$ & $10 \%$ & $7 \%$ & $24 \%$ \\
\hline \multirow{2}{*}{$5,001-11,000 \mathrm{CZK}$} & absolute & 22 & 37 & 35 & 55 & 149 \\
\cline { 2 - 7 } & relative $\%$ & $15 \%$ & $25 \%$ & $23 \%$ & $37 \%$ & $34 \%$ \\
\hline \multirow{2}{*}{$11,001-17,000 \mathrm{CZK}$} & absolute & 5 & 5 & 8 & 71 & 89 \\
\cline { 2 - 7 } & relative $\%$ & $6 \%$ & $6 \%$ & $9 \%$ & $80 \%$ & $20 \%$ \\
\hline \multirow{2}{*}{ above 17,001 CZK } & absolute & 5 & 7 & 6 & 75 & 93 \\
\cline { 2 - 7 } & relative $\%$ & $5 \%$ & $8 \%$ & $\mathbf{6} \%$ & $81 \%$ & $21 \%$ \\
\hline \multirow{2}{*}{ Total } & absolute & $\mathbf{9 1}$ & $\mathbf{7 8}$ & $\mathbf{5 9}$ & $\mathbf{2 0 8}$ & $\mathbf{4 3 6}$ \\
\cline { 2 - 7 } & relative $\%$ & $\mathbf{2 1} \%$ & $\mathbf{1 8 \%}$ & $\mathbf{1 4 \%}$ & $\mathbf{4 8} \%$ & $\mathbf{1 0 0} \%$ \\
\hline
\end{tabular}

More than a third of the students (37\%), from the largest category of disposable income 5,001 - 11,000 CZK, work more than 5 hours per day. Another quarter, 25\%, working 1-2 hours per day. Only $15 \%$ of students in this category of income does not work at all. There is an obvious increase in any time distribution for paid work, where $85 \%$ of all students in this category work an hour as minimum. The second largest income group (up to 5,000 CZK) more than half of them do not work at all. Income groups 11,001 - 17,000 CZK and above 17,001 CZK, indicate that more than $80 \%$ of students spend more than 5 hours of paid work.

- Testing criterion $\chi^{2}=193,9344$

- Number of degree of freedom $=(4-1) *(4-1)=9$

- Value of significance $5 \%, \alpha=0,05$

- Critical value for 9 degree of freedom $=16,919$

- $\mathrm{p}$-value $=2,484^{\mathrm{E}-41}$

- result: $\mathrm{p}$-value $<0,05 \mathbf{H}_{0}$ is rejected

Null hypothesis was rejected. Alternative hypothesis was accept the number of hours of paid work depends on the amount of disposable income. This finding is obvious from the contingency table (Tab. 5). Minimum 80\% of students with disposable income 11,001 CZK or more are engaged in paid work 5 hours and more.

\subsection{Consumer Basket by COICOP}

Comparing the structure of the consumer basket, students were again monitored according to the individual characteristics of groups of disposable income. Students fully decomposed their disposable income $(=100 \%)$ into 12 classes according to the national consumer basket by purpose COICOP. They did not take into account any level of savings. The average results for each category are shown in Tab. 6. 
The segmentation of disposable income was for the structure of the consumer basket left in 5 categories (up to 5,000 CZK; 5,001 - 11,000 CZK; 11,001 - 17,000 CZK; 17,001 - 23,000 CZK and 23,001 CZK above).

Tab. 6 - Consumer basket of College Students by Purpose COICOP (own processing)

\begin{tabular}{|c|c|c|c|c|c|c|c|c|c|c|c|c|c|}
\hline & & \multicolumn{12}{|c|}{ Classes of Consumer Basket by COICOP } \\
\hline 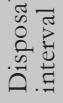 & 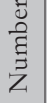 & C1 & C2 & C3 & C4 & C5 & C6 & C7 & C8 & C9 & C10 & C11 & C12 \\
\hline \multirow{2}{*}{ 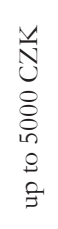 } & 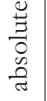 & 2456 & 601 & 1353 & 531 & 210 & 574 & 1402 & 425 & 896 & 242 & 1100 & 711 \\
\hline & 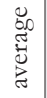 & $23 \%$ & $6 \%$ & $13 \%$ & $5 \%$ & $2 \%$ & $5 \%$ & $13 \%$ & $4 \%$ & $9 \%$ & $2 \%$ & $10 \%$ & $7 \%$ \\
\hline \multirow{2}{*}{ 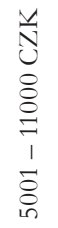 } & 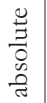 & 3534 & 941 & 1379 & 2203 & 365 & 592 & 1569 & 613 & 892 & 396 & 1596 & 812 \\
\hline & \begin{tabular}{l}
$\underbrace{}_{0}$ \\
\multirow{5}{5}{} \\
$\bar{~}$
\end{tabular} & $24 \%$ & $6 \%$ & $9 \%$ & $15 \%$ & $2 \%$ & $4 \%$ & $11 \%$ & $4 \%$ & $6 \%$ & $3 \%$ & $11 \%$ & $5 \%$ \\
\hline \multirow{2}{*}{ 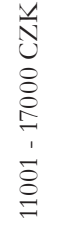 } & 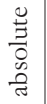 & 2050 & 337 & 782 & 1722 & 329 & 348 & 911 & 345 & 469 & 413 & 622 & 572 \\
\hline & 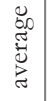 & $23 \%$ & $4 \%$ & $9 \%$ & $19 \%$ & $4 \%$ & $4 \%$ & $10 \%$ & $4 \%$ & $5 \%$ & $5 \%$ & $7 \%$ & $6 \%$ \\
\hline \multirow{2}{*}{ 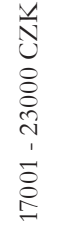 } & 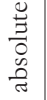 & 1284 & 216 & 420 & 1344 & 270 & 213 & 506 & 170 & 321 & 269 & 304 & 384 \\
\hline & 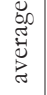 & $23 \%$ & $4 \%$ & $7 \%$ & $24 \%$ & $5 \%$ & $4 \%$ & $9 \%$ & $3 \%$ & $6 \%$ & $5 \%$ & $5 \%$ & $7 \%$ \\
\hline \multirow{2}{*}{ 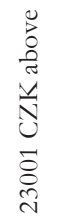 } & 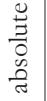 & 694 & 117 & 305 & 916 & 234 & 157 & 314 & 124 & 198 & 161 & 167 & 214 \\
\hline & 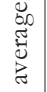 & $19 \%$ & $3 \%$ & $8 \%$ & $25 \%$ & $6 \%$ & $4 \%$ & $9 \%$ & $3 \%$ & $6 \%$ & $4 \%$ & $5 \%$ & $6 \%$ \\
\hline
\end{tabular}

In 2014, the structure does not change dramatically. It was confirmed that in lower income groups, the highest expenditure items include products belonging to class 1 (Food and non- 
alcoholic beverages), followed by class 7 (Transport) and 3 (Clothing and footwear). The lowest numbers are reflected in class 5 (Furnishings, household equipment and routine household maintenance) and again on Education (10).

From these calculated values a claim goes up, with the higher disposable income students has, the items from category 4 are moving up the rankings ahead to the first place. Spillover expenditures from the most representative class 1 to class 4 takes place in the income group level 11,001 to $17,000 \mathrm{CZK}$. This disposable income has $20 \%$ of the students. For higher income groups, above $17,000 \mathrm{CZK}$, a percentage of category 4 make up 24 - 25\% of the final consumption expenditure. These are followed by class 1 with $19-23 \%$ and class 7 with $9 \%$. At least consumer expenditures come from class 2 (Alcoholic beverages and tobacco) and newly from class 8 (Communications).

A comprehensive summary of the consumer basket for college student:

- Students with lower disposable incomes spend the most money per items in classes 1 (Food and non-alcoholic beverages), 7 (Transport) a 3 (Clothing and footwear).

- Students with higher disposable incomes spend most money in categories 4 (Housing, water, electricity, gas and other fuels), 1 (Food and non-alcoholic beverages) and 7 (Transport).

- Students with lower disposable income have the lowest consumer expenses in classes 10 (Education) and 5 (Furnishings, household equipment and routine household maintenance).

- Students with higher disposable incomes have the lowest financial expenses in the classes 2 (Alcoholic beverages and tobacco) and 8 (Communication).

- Spillover of consumer expenditures from class 1 to class 4 happens in the income level 11,001 - 17,000 CZK.

- Class 7 (Transport) has a permanent and substantial position in all income groups.

- Lower income groups have significantly higher consumer expenses than higher income groups in the class 2 (Alcoholic beverages and tobacco), 3 (Clothing and footwear), 9 (Recreation and culture) and 11 (Restaurants and hotels).

\subsection{Changes in Consumer Basket}

The connection with the changes in the level of students' disposable income were a part of the survey questions related to the increase or decrease theirs disposable income. These changes have been occurred in the structure of the consumer basket.

There is a higher wage expectation after university graduate. Students will enter into employment relationship (they will receive regular income) eventually it means for someone an increase in their current income. Contrary, the current disposable income could be reduced because of the loss of financial support from relatives/government, job loss, maternity/parental leave, retirement benefits. Tab. 7 below shows three categories of consumer basket which students ranked in each income level. 
Tab. 7 - Changes in Consumer Basket (structure by COICOP), (own processing)

\begin{tabular}{|l|c|c|c|c|c|c|c|}
\hline \multicolumn{8}{|c|}{ Changes in Consumer Basket (Classes by Purpose COICOP) } \\
\hline \multirow{2}{*}{$\begin{array}{l}\text { Disposable income } \\
\text { (DI) interval }\end{array}$} & \multicolumn{3}{|c|}{ Increase of DI } & \multicolumn{3}{c|}{ Decrease of DI } & \multirow{2}{*}{$\begin{array}{c}\text { No. } \\
\text { Students }\end{array}$} \\
\cline { 2 - 8 } & 1. & 2. & 3. & 1. & 2. & 3. & \\
\hline up to 5000 CZK & 9 & 3 & 5 & 3 & 2 & 9 & 105 \\
\hline $5001-11000$ CZK & 9 & 3 & 5 & 3 & 2 & 9 & 149 \\
\hline $11001-17000$ CZK & 9 & 3 & 5 & 3 & 2 & 9 & 89 \\
\hline $17001-23000$ CZK & 9 & 3 & 5 & 9 & 2 & 3 & 57 \\
\hline 23001 CZK above & 9 & 5 & 6 & 9 & 3 & 5 & 36 \\
\hline
\end{tabular}

In 2014 the students highlighted items from classes 9 (Recreation and culture), 3 (Clothing and footwear), 5 (Furnishings, household equipment and routine household maintenance) and rarely class 6 (Health) caused by an increase in disposable income. The students with higher income will raise consumer demand including products of recreation and cultural services.

In reverse, a decrease of disposable income were reflected in these classes: 3 (Clothing and footwear), 2 (Alcoholic beverages and tobacco) a 9 (Recreation and culture).

\section{DISCUSSION}

The consumer basket of students with a higher disposable income corresponds with the consumer basket as a national scale according to the CSO (2015). The controversy regarding the structure of the consumer basket is the group of students with lower incomes up to 11,000 CZK. These are full-time students without a full-time job and their consumer expenditures are different from part-time students.

Although these are the students with lower disposable incomes, they are also highly influenced by marketing tools such as price and various forms of discounts. (Osman and Fah, 2011) It should be stated that Czech students with low incomes are impulsive consumers who also seek for products of good quality. (Wanninyake, 2014) Still, their consumer basket has not shown high expenditures in category 10 (Education). The question is how their consumer basket will be influenced by the introduction of tuition fees for tertiary education by government. (Ebersole, 2012)

Organizations which offer a product portfolio in the field of recreation and culture can generate higher profits from these market segment students (in the case of employment and regular income). However, they can be at risk in case of another economic crisis, consumer pessimism, or the introduction of tuition fees, and therefore increase expenditures connected with education. We cannot forget the important role of companies that offer goods such as clothing and accessories. In this category, students have a huge potential across all segmentation criteria. On the contrary, these can be a threat of sales decline for other student expenses. 
Companies that should not worry about their income from sales due to decline in revenues or unexpected circumstances affecting consumer demand are those that offer food and soft drinks, leasing companies and financial institutions providing housing, gas station or transport operators and the companies from a pharmaceutical industry, etc.

\section{CONCLUSION}

A group of college students represents an increasingly larger segment in the market of goods and services. This situation emphasizes the national statistics and the objectives of EU strategy the Europe 2020. The number of college students in tertiary education in the Czech Republic has escalated from 291,000 to the current number of 371,000 students in the last 10 years.

The main aim was to show the structure of the consumer basket of college students in terms of the Czech Republic. Further on, the correlation between the number of hours devoted to paid work and the amount of disposable income has been revealed.

Students' consumer basket has revealed a difference in the structure of students with lower vs. higher disposable incomes. Students with lower incomes have higher consumer expenditure, primarily in the categories 1 (Food and non-alcoholic beverages), 4 (Housing, water, electricity, gas and other fuels), 7 (Transport) and 3 (Clothing and footwear). There is a presumption that students with lower incomes are full-time students and do not have a regular income from a full time job. Students with higher incomes, presumably part-time students, are working people who spend their disposable incomes mainly in classes 4 (Housing, water, electricity, gas and other fuel), 1 (Food and non-alcoholic beverages) and 7 (Transport). The items of categories 1, 4 and 7 have an essential role in the consumer basket for any type of a student.

A change in the structure of the consumer basket caused by increasing disposable incomes (e.g. entering the job market after university graduation or having a higher wage assessment is mainly reflected in the following consumer basket items: 9 (Recreation and Culture), 3 (Clothing and footwear) and 5 (Furnishings, household equipment and routine household maintenance). On the contrary, a decrease in disposable income will mostly reduce expenses regarding the following items in the categories 3 (Clothing and footwear), 2 (Alcoholic beverages and tobacco) and 9 (Recreation and Culture). The most essential items subjectively perceived by consumers are from

the following classes 1 (Food and non-alcoholic beverages), 4 (Housing, water, electricity, gas and other fuels) and 7 (Transport).

\section{References}

1. Banarova, M. (2014). Students' Satisfaction as a Competitive Advantage in the Financial Products Market: A Comparative Study. Journal of Competitiveness, 6(1), 104-123. doi:10.7441/ joc.2014.01.07

2. Besanko, D. A., Braeutigam, R. A., \& K. Rockett. (2015). Microeconomics. (Vol. 5). NJ: Wiley.

3. Česko (1998). Zákon č. 111/1998 Sb. Retrieved September 19, 2015, from: http://www. msmt.cz/vzdelavani/vysoke-skolstvi/zakon-c-111-1998-sb-o-vysokych-skolach-text-sezapracovanymi 
4. Clemons, E. K. (2008). How Information Changes Consumer Behavior and How Consumer Behavior Determines Corporate Strategy. Journal of Management Information Systems, 25(2), 13-40. doi:10.2753/mis0742-1222250202

5. Cooper, D. R., \& Schindler, P. S. (2008). Business research methods. Boston: McGraw-Hill Irwin.

6. Czech Statistical Office (2012a). Statistiky: Statistika rodinných úctů-Metodika. Retrieved May 20, 2015, from: https://www.czso.cz/csu/czso/rodinne_ucty

7. Czech Statistical Office (2012b). Vydáváme: Tiskové zprávy, Modely prédpokládaného vývoje trhu práce. Retrieved May 27, 2015, from: http://www.czso.cz/csu/tz.nsf/i/modely_ predpokladaneho_vyvoje_trhu_prace_v_cr_do_roku_2050_20121115

8. Czech Statistical Office (2014a). Statistiky: Studenti a absolventi terciárníbo stupnè vadèlávání. Retrieved May 17, 2015, from https:// www.czso.cz/csu/czso/studenti_a_absolventi_ terciarniho_stupne_vzdelavani

9. Czech Statistical Office (2015a). Databases: GDP, national accounts; Gross domestic product (GDP) - Expenditure approach. Retrieved May 20, 2015, from https:// .caplzso. $\mathrm{cz} / \mathrm{pll} /$ rocenka/rocenkavyber.makroek_vydaj

10. Czech Statistical Office (2015b). Statistiky: Indexy spotrebitelských cen - revizęe. Retrieved May 27, 2015, from https://www.czso.cz/csu/czso/indexy_spotrebitelskych_cen_revize

11. Czech Statistical Office (2015c). Statistics: Employment \& Unemployment. Retrieved May 27, 2015, from https://www.czso.cz/csu/czso/employment_unemployment_ekon

12. Czech Statistical Office (2015d). Vydáváme: Vydáni a spotreba domácností statistiky rodinných úctù - domácnosti podle postaveni osoby v čele, podle velikosti obce, príjmová pásma, regiony soudr:̌nosti - 2014 [online]. Retrieved May 15, 2015, from https://www.czso.cz/csu/czso/vydani-a-spotrebadomacnosti-statistiky-rodinnych-uctu-za-rok-2014-domacnosti-podle-postaveni-osoby-vcele-podle-velikosti-obce-prijmova-pasma-regiony-soudrznosti

13. Czech Statistical Office (2015e). Vydáváme: Časové rady, Česká republika od roku 1989 v číslech. Tab.12.08. Vysoké skooly [online]. Retrieved May 15, 2015, from http://www.czso.cz/cz/cr_ 1989_ts/1208.pdf

14. Ebersole, B. J. (2012). Student Success Evolves from Expectation to Responsibility. Community College Week. 25(2), p 4-4, 2/3p.

15. Enache, I. C. (2011). Customer Behavior And Student Satisfaction. Bulletin of the Transilvania University of Brasov. Series V: Economic Sciences. 4(2), 41-46.

16. Enis, B. M., Cox, K. K., \& Stafford, J. E. (1972). Students as Subjects in Consumer Behavior Experiments. Journal of Marketing Research, 9(1), 72. doi:10.2307/3149612

17. Eurostat (2015a). Consumption Expenditure of Private Households. Retrieved May 27, 2015. Retrieved from http://ec.europa.eu/eurostat/cache/metadata/en/hbs_esms.htm

18. Eurostat (2015b). Europe 2020 Strategy. Main indicators. Retrieved May 15, 2015, from http:// ec.europa.eu/eurostat/web/europe-2020-indicators/europe-2020-strategy 
19. Eurostat (2015c). National accounts (including GDP); Main tables: Final consumption expenditure of households. Retrieved May 27, 2015, from http://ec.europa.eu/eurostat/web/ national-accounts/data/main-tables

20. Fiala, P. Interview. (2012, December 22). Interview ČT24. [online]. Retrieved from http:// www.ceskatelevize.cz/ct24/domaci/208520-fiala-prioritou-je-kvalita-nikoliv-zapisne/.

21. Gurney, P., Chambers, E., Grant, L., Shah, S., \& Sullivan, M. (2004). The Internet: Marketing Researcher's Panacea or Pandora's Box? Marketing Review 4(1). 27-45.

22. Halawah I. (2011). Factors Influencing College Students' Motivation to Learn From Students' Perspective. Education. 132(2), 379-390.

23. Krugman, P. R., \& Wells, R. (2013b) Microeconomics. (Vol. 3). New York: Worth Publishers.

24. Kuběnka, M., \& Ptáčková, P. (2011). Marketing of banks - segment of students. Scientific Papers of the University of Pardubice. Series D, Faculty of Economics. 16(20): 28-39.

25. La Roche, C. R., Flanigan, M. A., \& Copeland Jr, P. K. (2010). Student housing: Trends, preferences and needs. Contemporary Issues in Education Research (CIER), 3(10), 45-50.

26. Luquis, R. R., Brelsford, G. M., \& Rojas-Guyler, L. (2012). Religiosity, spirituality, sexual attitudes, and sexual behaviors among college students. Journal of religion and health, 51(3), 601-614. doi:10.1007/s10943-011-9527-z

27. Mankiw G. N., \& M. Taylor. (2014). Macroeconomics (Vol. 3). Andover: Cengage Learning.

28. Miller, R. K., \& Washington, K. (2013). 'Part IX: Segamnetation: Chapter 46: College Student's, Consumer Behavior, 277-279. Retrieved May 10, 2015, from: EBSCOhost.

29. MŠMT, C2013-2015b. Tiskové zprávy; Ministr školství představil návrh vysokoškolského zákona. Retrieved May, 20, 2015, from http://www.msmt.cz/ministerstvo/novinar/ministrchladek-spolu-s-rektory-predstavil navrh?highlightWords=novela + vysoko $\mathrm{C} 5 \% \mathrm{~A} 1 \mathrm{kolsk} \% \mathrm{C}$ $3 \% \mathrm{~A} 9 \mathrm{ho}+\mathrm{z} \% \mathrm{C} 3 \% \mathrm{~A} 1 \mathrm{kona}$

30. O'connor, L., \& Lundstrom, K. (2011). The Impact of Social Marketing Strategies on the Information Seeking Behaviors of College Students. Reference \& User Services Quarterly. 50(4), 351-365. doi:10.5860/rusq.50n4.351

31. Rubinfeld, R. S., \& Pindyck, D. L. (2013). Microeconomics. (Vol. 8) N.J: Pearson Prentice Hall.

32. Schiffman, L. G., \& Kanuk, L. L. (2007). Consumer behavior. (Vol. 9). N.J.: Pearson Prentice Hall.

33. Stávková, J., \& Stejskal, L. (2011). Structure and Determinants of Consumer Expenditures. Ekonomie a management. 14(2), 45.

34. Wanninayake W.M.C.Bandara (2014). Consumer Decision-Making Styles and Local Brand Biasness: Exploration in the Czech Republic. Journal of Competitiveness, 6 (1), 3-18. doi:10.7441/joc.2014.01.01

35. Wells, R. S., \& Lynch, C. M. (2012). Delayed College Entry and the Socioeconomic Gap: Examining the Roles of Student Plans, Family Income, Parental Education, and Parental Occupation. The Journal of Higher Education, 83(5), 671-697. doi:10.1353/jhe.2012.0028. 
36. Xiao, J. J., Tang, C., Serido, J., \& Shim, S. (2011). Antecedents and Consequences of Risky Credit Behavior Among College Students: Application and Extension of the Theory of Planned Behavior. Journal of Public Policy \& Marketing, 30(2), 239-245. doi:10.1509/ jppm.30.2.239

37. Yang, W.-C., Chen, K.-C., Hsueh, Y.-S., Tan, C.-P., \& Chang, C.-M. (2012). The Relationship Between Leisure and Well-Being in Taiwanese College Students. Soc Behav Personal, 40(8), 1245-1254. doi:10.2224/sbp.2012.40.8.1245

38. Yin-Fah, B. C., Osman, S., \& Foon, Y. S. (2011). Simulation of Sales Promotions towards Buying Behavior among University Students. International Journal of Marketing Studies, 3(3). doi:10.5539/ijms.v3n3p78

39. Zilberman, J., \& Poole, B. (2009). Spending Practices of College Students: Alcohol. Proceedings for the Northeast Region Decision Sciences Institute (NEDSI). 267-269.

\section{Contact information}

Ing. Monika Horáková. Ph.D.

Tomas Bata University in Zlin, Faculty of Management and Economics

Mostni 5139, 76001 Zlin, Crech Republic

E-mail:mhorakova@fame.utb.cz. 